\author{
www.ijabpt.com Volume-4, Issue-4, Oct-Dec-2013 Coden : IJABPT Copyrights@2013 \\ ISSN : 0976-4550 \\ Received: $10^{\text {th }}$ August $-2013 \quad$ Revised: $07^{\text {th }}$ Sept-2013 Accepted: $13^{\text {th }}$ Sept-2013 \\ Review article
}

\title{
PERFORMANCE OF DIFFERENT LEVELS OF NITROGEN AND PHOSPHORUS ON OIL YIELD AND OIL QUALITIES OF PALMAROSA (CYMBOPOGAN MARTINI VAR. MOTIA) A- REVIEW
}

\author{
Jayalakshmimitnala and Mohanaraopuli \\ Department of soil science and Agricultural chemistry, Dr. Panjabrao Deshmukh Krishi Vidya Peeth, Akola, \\ M.S India 444104 \\ jayalakshmimitnala@gmail.com
}

\begin{abstract}
Cymbopogan martini var. Motia commonly known as Palmarosa or Rosha grass is a tall perennial tufted hedge native of most parts of sub-tropical India. Palmarosa oil has a sweet floral rose-like odour also has notes of rye bread, tea and clary sage. The oil is extensively used as perfumery raw material in soaps; floral rose-like perfumes; cosmetics preparations and in the manufacture of mosquito repellent products. It is used for flavoring tobacco products, foods and non-alcoholic beverages. The volatile oil is used as a remedy for lumbago, stiff joints, skin diseases and for bilious complaints "Considering the importance of this crop every effort is made to increase the oil production of the crop by using improved nutrient management practices. The supply of inorganic fertilizers in appropriate quantity form and stage of crop growth could upgrade the quality and yields remarkably”.
\end{abstract}

Key words, oil quality, oil yield and Palmarosa

\section{INTRODUCTION}

Palmarosa (Cymbopogan martinii var. Motia) oil is very rich in geraniol (75-90\%) present both in free and bound form and oil is thus source of high grade geraniol for cosmetics and perfumery industry. Gultai (1963) has studied the distribution in different districts of Maharashtra together with distillation practices and quality of oil produced from forest collections. The herb containing flowering tops and foliage on distillation yield a colourless to pale (greenish) yellow essential oil emitting a sweet scented rose like aroma. Maximum oil yield in Cymbopogan martinii var. Motia has been reported at commencement of flowering, while the total yield was more at most flower open stage followed by early seed formation stage and these oils meet general ISI speciations. A superior rosecous green odour is found in the oil produced at early stage (Pareek et al., 1982). India has a sizable market and export and is the principal producers of Palmarosa oil, in recent years have ranged between Rs 2.8 and 5.0 million annually (Gupta et al., 1995). The oil contains geraniol and its esters (90-95\%). Other constituents are dipentene, methyl heptanone (responsible for mosquito repellent property) and farnesol. Ginger grass oil extracted from the leaves of Sofia is inferior to Palmarosa oil and has a peculiar oily and sweet odour. The studies have shown that Palmarosa oil is a unique oil having a roseceous odour with slight touch of typical aroma coming from the curst of freshly baked rye bread. It is distinct and superior to the oil of Jamrosa in composition and odour (Maheshwari et al., 1988). Absence of N\&P fertilization yielded essential oil with low aldehyde and citral contents but of very high geraniol content. Addition of $\mathrm{N}$ increased the percentage of constituents containing hydroxyl groups. Phosphate fertilization reduced the percentage of constituents with carbonic group. $\mathrm{N}$ and $\mathrm{P}$ level did not affect specific gravity and refractive index of oil (Dahatonde et al. 1986). Keeping in view the scientific research requirements, the present investigation was set up to evaluate different levels of nitrogen and phosphorus on oil qualities of rainfed palmarosa

\section{Effect of nitrogen on oil yield and quality of Palmarosa}

Chandra (1972) pointed out the increasing application of nitrogen has increased essential oil yield of Citronella crop. Thus, as high as $150 \mathrm{~kg} \mathrm{~N}+50 \mathrm{~kg} \mathrm{P}+50 \mathrm{~kg} \mathrm{~K}$ per hectare per year was suggested to obtain optimum yield.

Sarma et al. (1977) observed that the application of $\mathrm{N}$ fertilizer increased the herbage and Palmarosa oil yield, suggested the use of $80 \mathrm{~kg} \mathrm{~N}$ per ha together with each $40 \mathrm{~kg} \mathrm{P}$ and $\mathrm{K} \mathrm{ha}^{-1}$ has gave high herb and oil yield in Palmarosa than the control. 
Nair et al. (1979) conducted on experiment on the relative performance of 3 Lemon grass (Cympogon flexuosus) varieties, viz., OD-19, SD-68 and RRL-16 and their response to 3 levels of nitrogen $(0,50,100 \mathrm{~kg} / \mathrm{ha})$ have been reported. The order of superiority with regard to oil yield and citral content was SD-68, OD-19 and RRL-16, however RRL-16 gave the highest percentage of oil recovery. Increased dose of $\mathrm{N}$ did not increase the citral content in any of the varieties. Bommegowad et al. $\left(1980^{\mathrm{b}}\right)$ revealed that with the increase in level of nitrogen from 75 to 100 $\mathrm{kg} / \mathrm{ha} / \mathrm{harvest}$ increased the oil yield by 30 per cent in Java citronella.

Pareek et al. (1981) revealed that $\mathrm{N}$ at $40 \mathrm{~kg} / \mathrm{ha}$ gave significantly highest herbage and oil yield which increased in subsequent harvests in Palmarosa. The quality of oil was slightly improved at $40 \mathrm{~kg} \mathrm{~N} / \mathrm{ha}$ due to increase in percentage of geraniol in the oil. The application of $\mathrm{P}$ and $\mathrm{K}$ did not influence the yield and quality under cultivation.

Rajan et al. (1984) revealed that OD-19 and SD-68 Lemon grass varieties were at par and significantly superior to RRL-16 in grass production and oil yield. RRL-16 recorded maximum oil content and minimum citrol percentage. Effect nitrogen on grass and oil yield was significant. Levels of $100 \mathrm{~kg} \mathrm{~N}$ and $50 \mathrm{~kg} \mathrm{~N}$ were at par and superior to control in oil yield, but $50 \mathrm{~kg} \mathrm{~N} / \mathrm{ha}$ was at par with $100 \mathrm{~kg} \mathrm{~N} / \mathrm{ha}$ and control in the case of grass yield. Oil content was maximum at higher nitrogen levels compared to control in most of the harvests. Prakasha Rao et al. (1985 ) observed that the application of $200 \mathrm{~kg} \mathrm{~N} \mathrm{ha}^{-1} \mathrm{yr}^{-1}$ had significantly increased the herb and oil yield of Java citronella but did not respond to $\mathrm{P}$ and $\mathrm{K}$ fertilizers. Rao et al. (1990) evaluated that the net profit was maximum with spacing $45 \mathrm{x} 30$ and annual application of $160 \mathrm{~N} \mathrm{~kg} \mathrm{ha}{ }^{-1}$ produced the highest amount of biomass and essential oil of Palmarosa grass. Vitkare et al. (1990) stated that the average oil content in foliage was significantly increased in all four cutting by nitrogen fertilization. Application of $40 \mathrm{~kg} \mathrm{~N} / \mathrm{ha}$ with $20 \mathrm{~kg}$ P/ha increased the oil content in third and fourth cutting. Also reported the application of phosphorus alone did not show any significant effect on average oil in Lemon grass.

Rao et al. (1991) concluded that the $100 \mathrm{~kg}$ N/ha has significantly increased the herb and Citronella oil yield over control in the first two years. Pal et al. (1992) revealed that there was no significant difference in herb and oil yield of Java citronella due to increase of various nitrogen doses between 120 to $180 \mathrm{~kg}$ per hectare during $\mathrm{I}^{\mathrm{st}}$ year. However, maximum yield of herb (46.5 $\left.\mathrm{t} \mathrm{ha}^{-1}\right)$ and oil $\left(225.3 \mathrm{~kg} \mathrm{ha}^{-1}\right)$ were obtained under dose of $180 \mathrm{~kg} \mathrm{~N}^{-1}$ which was 24.66 and 21.7 per cent higher than the yield of herb and oil under control. In $2^{\text {nd }}$ year crop the highest dose of $340 \mathrm{~kg} \mathrm{~N} \mathrm{ha}^{-1}$ gave significant increase in both herb and oil yield over the other treatments. The herb $\left(83.7 \mathrm{t} \mathrm{ha}^{-1}\right)$ and oil $(383.7 \mathrm{~kg}$ $\mathrm{ha}^{-1}$ ) yield under treatment was 66.5 and 47.8 per cent higher than control. The citral content of oil did not affect much with graded doses of nitrogen in both years. Maheswari et al. (1995) conducted a field experiment with C. martinii var. Motia during 3 consecutive Kharif (rainy) seasons under partially irrigated conditions. The effects of Azotobacter biofertilizer and 40 and $80 \mathrm{~kg} \mathrm{~N} / \mathrm{ha}$ applied alone or in combination were studied. Azotobacter was applied to roots in the first year and liquid form of Azotobacter was applied as a drench at $10 \mathrm{~kg} \mathrm{ha}^{-1}$ in the root zone in the second and third years. Application of Azotobacter resulted in 10.3 to 39.6 and 11.7 to $35.2 \%$ higher herbage and oil yields respectively than control. These results were comparable with those obtained with $40 \mathrm{~kg} \mathrm{~N} \mathrm{ha}^{-1}$ and 40 and $80 \mathrm{~kg} \mathrm{~N}^{\mathrm{N}} \mathrm{ha}^{-}$ ${ }^{1}+$ Azotobacter. Application of $80 \mathrm{~kg} \mathrm{~N} \mathrm{ha}^{-1}$, however resulted in higher oil yield than any other treatment. Muni Ram et al. (1997) investigated the effects of $\mathrm{N}$ on the yield (herb and essential oil) of Cymbopogon martinii during 1989-91. Application of $100 \mathrm{~kg} \mathrm{~N} \mathrm{ha}^{-1}$ maximized herb $\left(27.6 \mathrm{t} \mathrm{ha}^{-1}\right)$ and essential oil yields $\left(123.5 \mathrm{~kg} \mathrm{ha}^{-1}\right)$ in the first year. At least $150 \mathrm{~kg} \mathrm{~N} \mathrm{ha}^{-1}$ was required in following years to maximize yields (38.4 and $164.8 \mathrm{~kg} \mathrm{ha}^{-1}$ of herb and essential oils, respectively). Khode et al. (1999) conducted a field experiment during 1988-90 at Akola (Maharashtra) with Palmarosa to study the effect of different spacing (30 x 30, $30 \times 45$ and $30 \times 60 \mathrm{~cm}$ ) and N fertilizer rates $(25.50,75$ and $\left.100 \mathrm{~kg} \mathrm{ha}^{-1}\right)$ an herbage and oil yield. Spacing at $30 \times 60 \mathrm{~cm}$ gave the highest dry herbage yield (48.3 and $117.6 \mathrm{t}$ $\mathrm{ha}^{-1}$ during 1988-89 and 1989-90 respectively). $\mathrm{N}$ application at 75 or $100 \mathrm{~kg} \mathrm{ha}^{-1}$ gave higher herbage yields than the lower $\mathrm{N}$ rate. With regarding to oil yield, spacing $30 \times 60 \mathrm{~cm}$ was best in both the years. $\mathrm{N}$ fertilizer application at 75 or $100 \mathrm{~kg} \mathrm{ha}^{-1}$ gave the highest oil yields. Ram et al. (1999) observed that the fresh herbage and citronella oil, yield (343 $\mathrm{kg} \mathrm{ha}^{-1} \mathrm{yr}^{-1}$ ) were increased by the application of $\mathrm{N}$ up to $200 \mathrm{~kg} \mathrm{ha}^{-1} \mathrm{yr}^{-1}$.

\section{Effect of phosphorus on oil yield}

Sharma et al. (1980) revealed that in Palmarosa the application of $150 \mathrm{~kg} \mathrm{~N}$ and $50 \mathrm{~kg} \mathrm{P} \mathrm{ha}^{-1}$ significantly increased the herbage and oil yield at all the harvest stages of Palmarosa crop. The per rupee investment of on nitrogen fertilizer it was stated the application of $75 \mathrm{~kg} \mathrm{~N}^{-1}$ increased $42 \mathrm{~kg}$ oil ha ${ }^{-1} \mathrm{yr}^{-1}$ and gave net return Rs. 24.38 which was decreased to Rs. 18.87 when the rate of $\mathrm{N}$ application was raised to $150 \mathrm{~kg} \mathrm{ha}^{-1}$. The application of $50 \mathrm{~kg}^{\mathrm{P}} \mathrm{ha}^{-1}$ increased the oil by 3.9, 1.2, 2.8 and $5.6 \mathrm{~kg} \mathrm{ha}^{-1}$ in first second third and fourth harvest respectively gave an overall increase of $13.5 \mathrm{~kg}$ oil ha $\mathrm{yr}^{-1}$ and return of Rs. 11.73 on spent of each rupee of phosphate. 
Munsi and Mukherjee (1982) observed the significant increase in the yield of oil by application of nitrogenous as well as phosphotic fertilizer. Mentha, Citronella and Palmarosa showed maximum benefit with 100, 120 and $60 \mathrm{~kg}$ nitrogen per hectare respectively. The most effective level of phosphorus was $60 \mathrm{~kg} \mathrm{ha}^{-1}$ irrespective of the crop. Maximum profit was obtained under highest level of nitrogen and phosphorus in combination. The quality of oil also improved due to the application of fertilizers.

Dahatonde et al. (1986) revealed that absence of $\mathrm{N}$ and $\mathrm{P}$ fertilization yielded essential oil with low aldehyde and citral contents but of very high gereniol content. Addition of $\mathrm{N}$ increased the percentage of constituents containing hydroxyl groups. Phosphate fertilization reduced the percentage of constituents with carbonic group. $\mathrm{N}$ and $\mathrm{P}$ level did not affect specific gravity and refractive index of oil.

Maheswari et al. (1993) found that the application of $30 \mathrm{~kg} \mathrm{~N}+30 \mathrm{~kg} \mathrm{P} \mathrm{ha}^{-1}$ with 15 tonnes of FYM and $50 \mathrm{~kg} \mathrm{Zn} \mathrm{ha}^{-1}$ increased the mean herb and Palmarosa oil yield by 39 and $46 \%$, respectively when compared with control.

The maximum growth and oil yield (120 lit ha ${ }^{-1} \mathrm{yr}^{-1}$ ) of lemongrass obtained with the application of $30 \mathrm{~kg} \mathrm{~N}+30 \mathrm{~kg} \mathrm{P}$ $+30 \mathrm{~kg} \mathrm{~K} \mathrm{ha}^{-1}$ year. (Anon, 2002).

\section{Combined effect of nitrogen and phosphorus on oil yield}

Ghosh and Chatterjee (1976) found that application of 65:50:40 kg NPK per hectare in Lemon grass and Palmarosa grass respectively increased the vegetative growth, hastened flowering and enhanced the oil content in both the species when compared with unfertilized plants. Fertilizing at double the rate conferred no advantage and was after detrimental effect. Randhawa and Mahey (1985) recorded the beneficial effect of nitrogen upto the $75 \mathrm{~kg} / \mathrm{N} / \mathrm{ha}$ and application of $40 \mathrm{~kg}$ P/ha showed significant depressive effect on herb and Citronella oil yield.

Chatterjee and Ghosh (1973) stated that the application of 60:45:35 kg NPK per hectare produced optimum vegetative growth herbage and oil yield of Citronella than control in hilly tracts and Gangetic plains of West Bengal.

Husain (1979a) conducted trials on Citronella (Java) with an aim to determine the optimum requirement of NPK nutrients for Citronella crop. The trials included four levels of nitrogen $\left(0,40,80\right.$ and $\left.120 \mathrm{~kg} \mathrm{ha}^{-1}\right) 3$ levels of $\mathrm{P}_{2} \mathrm{O}_{5}(0$, 40 and $\left.80 \mathrm{~kg} \mathrm{P}_{2} \mathrm{O}_{5} \mathrm{ha}^{-1}\right)$ and 2 levels of $\mathrm{K}_{2} \mathrm{O}\left(0\right.$ and $40 \mathrm{~kg} \mathrm{~K}_{2} \mathrm{O}$ ha $\left.^{-1}\right)$ were used in randomized block design. Three cuttings were taken each year. Two years data indicated that fresh herb yield increased significantly up to $80 \mathrm{~kg} \mathrm{~N}^{-1}$ and $40 \mathrm{~kg} \mathrm{P}_{2} \mathrm{O}_{5}$ ha $^{-1}$ in both the years. Further increase in the levels of $\mathrm{N}$ and $\mathrm{P}$ could not increase the herbage yield significantly. Application of potassium did not influence the yield significantly.

Virmani et al. (1977) concluded the application of $30 \mathrm{~kg}$ each of NPK per hectare as a basal dose $60 \mathrm{~kg} \mathrm{~N}^{-1}$ in 3 to 4 splits annum as top dressing during growing season of Lemon grass was found beneficial than control.

Gupta et al. (1978) recorded large number of reports on fertilizer use in Palmarosa in different parts of the country and concluded that highest dose of NPK ( $80 \mathrm{~kg} \mathrm{ha}^{-1}$ of each) in succeeding cutting responded significantly in increased the plant height and number of tillers of the plant over control. The favorable significant effect of $\mathrm{P}$ and $\mathrm{K}$ was observed only upto $40 \mathrm{~kg} \mathrm{ha}^{-1}$ of dose. The higher oil yield were obtained due to the interaction of higher doses of N $80 \mathrm{~kg}$ combination with $40 \mathrm{~kg}$ each $\mathrm{P}$ and $\mathrm{K} \mathrm{ha}^{-1}$. Hazarika et al. (1978) considered that the $60 \mathrm{~kg} \mathrm{~N}, 40 \mathrm{~kg} \mathrm{P}$ and $40 \mathrm{~kg} \mathrm{~K} \mathrm{ha}^{-1}$ was optimum level for the production of highest herbage and oil yield in Palmarosa than control (or) unfertilized. Singh et al. (1983) conducted field trial on C. winterianus to study the response of different levels of N, P and K during 1978-79 and 1979-80. A combination of $80 \mathrm{~kg} \mathrm{~N}$ with $40 \mathrm{~kg} \mathrm{P}_{2} \mathrm{O}_{5}$ ha $^{-1}$ without potassium in each year under the agroclimatic conditions of present experimentation, was found suitable for setting optimum herb and oil yields. Oil content could not be altered by different levels of N, P and K in both the years. Dahatonde et al. (1982) reported the application of $40 \mathrm{~kg} \mathrm{~N}+20 \mathrm{~kg} \mathrm{P}+20 \mathrm{~kg} \mathrm{~K}$ per hectare had produced optimum yield of herbage and Lemon grass oil at each cutting than control. Maheswari et al. (1984) reported that plant height grass dry weight and fresh herbage yields/ha were significantly increased over control up to application of $60 \mathrm{~kg} \mathrm{~N}+30 \mathrm{~kg} \mathrm{P}+30 \mathrm{~K} \mathrm{ha}^{-1} \mathrm{yr}^{-1}$. Herbage yield was highest during first and second year but decreased in the third year. Palmarosa oil yield/ha was highest in second year. Munsi et al. (1989) investigated the effects of $\mathrm{N}\left(0,20,40\right.$ and $\left.60 \mathrm{~kg} \mathrm{ha}^{-1}\right)$ and $\mathrm{P}\left(0,40,60\right.$ and $\left.80 \mathrm{~kg} \mathrm{ha}^{-1}\right)$ on the yield and quality of essential oil from Palmarosa (Cymbopogon martinii) in the field at Calcutta during 1977-1980. Essential oil yield increased with increasing rate of N. Essential oil yield increased following application of P but no significant differences in yield were recorded between treatments.

Singh et al. (1994) suggested that maximum plant height, tillers plant, total dry matter $\left(45.14 \mathrm{t} \mathrm{ha}^{-1}\right)$, mean content $(1.75 \%)$ and total citronella oil $\left(233\right.$ lit ha $\left.^{-1}\right)$ obtained at application of optimum dose of NPK combination at $120+40$ $+40 \mathrm{~kg} \mathrm{NPK} \mathrm{ha}^{-1}$, respectively in Citronella. 
Santhi and Vijaykumar (1998) conducted a field experiment at Coimbator (Tamilnadu), India during 1994-96, Palmarosa (Cymbopogan martinil) seedlings were dipped in biofertilizer (Azospirillum) for 20 min before transplanting. $\mathrm{N}$ as urea applied at $0,10,20,30$ or $40 \mathrm{~kg} \mathrm{ha}^{-1}$ together with $\mathrm{P}_{2} \mathrm{O}_{5}$ at $50 \mathrm{~kg} \mathrm{ha}^{-1}$, together with the Azospirillum dip resulted in the best growth and yield attributing characters such as number of leaves/plant, number of tillers plant ${ }^{-1}$, leaf number inflorescence number and highest herbage and essential oil yields ha ${ }^{-1}$.

The higher herbage yield and oil yield was produced with based application of $40 \mathrm{~kg}$ each NPK/ha and $60 \mathrm{~kg} / \mathrm{ha}$ top dressed gave 20 tonnes fresh herbage yield with 250-300 kg Citronella oil/ha in 2 year cycle (Anon 2001).

The application of $75 \mathrm{~kg} \mathrm{~N}+60 \mathrm{~kg} \mathrm{P}+40 \mathrm{~kg} \mathrm{~K} \mathrm{ha}^{-1}$ in Palmarosa gave highest herbage yield $20 \mathrm{t} \mathrm{ha}^{-1}$ with $200 \mathrm{~kg}$ oil yield ha-1 (Anon, 2001).

\section{CONCLUSION}

Considering the importance of this crop every effort is made to increase the oil production of the crop by using improved nutrient management practices. Since, the encouraging results obtained may serves as a guidelines to the Palmarosa growers to adopt suitable technologies for higher yield.

However, the experiment is conducted only for one year it needs further conformation.

\section{REFERENCES}

Anonymous. (2001). Hand Book of Horticulture, ICAR, New Delhi pp 614-624.

Anonymous. (2001). Market Grands in Production Price Export Import etc. Chemical Marketing Reporter 257(22, 23\&24), CIMAP Records.Anonymous. 2002. PKV Dairy. pp 228.

Bommegowada, A., S. Joshi, M. R. Narayana and K. Krishnamurthy. (1980). Effect of nitrogen nutrition on oil per cent and oil glands in Java citronella (Cymbopogon winterianus Jowitt). Mysore J. Agri. Sci. 14 : 477-479.

Chandra, V. (1972). Effect of varying concentration of NPK fertilizers on yield and oil of Cymbopogon winterianus Jowitt. Indian Perfum, 16(1): 52-55.

Chatterjee, S. K. and M. L. Ghosh. (1973). Cultivation of essential oil yielding plants in the hilly tracts and Gangetic plains of West Bengal. Indian Perfum. 17(1): 31-34.

Dahatonde, B. N. and S. N. Fasate. (1986). (Nagarjun Med. Aromot. Pl. Res. Scheme, PKV Akola, Maharashtra, India) Effect of $\mathrm{N}$ and $\mathrm{P}$ on lemongrass in relation to oil and its quality. Panjabrao Krishi Vidyapeeth. Res. J. 10(2): 152-153.

Gulati, B. C. (1963). Present position of Palmarosa and ginger grass oils industry. Scope of systematic cultivation of Palmarosa. Indian Oil and Soap. 29(4): 87-111.

Gupta, R., S. K. Pareek and M. L. Maheswari. (1995). Advances in horticulture. Medicinal and Aromatic Plants. pp 736-747.

Dahatonde, B. N., B. G. Joshi and D. G. Vitkare. (1982). Studies on the effect of nitrogen and phosphorus application on foliage and oil yield of lemon grass Proc. National seminar on medicinal and aromatic plants held at Tamil Nadu Agricultural University Coimbtore. pp 156-157.

Dahatonde, B. N. and S. N. Fasate. (1986). (Nagarjun Med. Aromot. Pl. Res. Scheme, PKV Akola, Maharashtra, India) Effect of $\mathrm{N}$ and $\mathrm{P}$ on lemongrass in relation to oil and its quality. Panjabrao Krishi Vidyapeeth. Res. J. 10(2): 152-153.

Dutta, P. K. and S. C. Paul. (1976). Effect of fertilizers on the herb yield and oil content of Palmarosa grass (Cymbopogon martinii Var. Motia). Medicinal and Aromatic Plants. GAU Anand. pp 112.

Ghosh, M. L. and S. K. Chatterjee. (1976). Effect of N, P and K on growth and essential oil content of two species of cymbopogon. Sci. Cult. 42(1): 490. 
Gupta, R., M. L. Maheswari, R. D. Singh, J. Mohan, G. K. Gupta. (1978). Effect of fertilizers on yield, oil content and oil composition of Palmarosa oil grass as influenced by seasonal variations. Indian Perfum. 22(2): 79-87.

Hazarika, J. N., A. Baura, A. K. A. Barua. (1978). Effect of NPK fertilizers on the yield and quality of Palmarosa (Cymbopogon martinii Var. Motia) under the influence of seasonal variations. Indian Perfum. 22(1): 36-39.

Husain Akhtar. (1979). Response of citronella (Java) to NPK fertilizers under Tarai conditions of Uttar Pradesh. Annual Report of CIMAP. Regional Central, Pantnagar. pp 31.14(3) : 112-113.

Khode, P. P., P. U. Ghatol, M. Dhumaiv and N. N. Mahakal. (1999). Effect of spacing and nitrogen levels on foliage and oil yield of Palmarosa grass (Cymbopogon martinii). Nagarjun Medicinal Plant Garden, Dr. PDKV, Akola, India. Agricultural Science Digest Kernal. 19(4) : 264-266.

Maheswari, S. K., S. K. Gangrade and R. K. Sharma. (1995). Differential responses of Azotobactor and Nitrogen on Biomass and Oil yield of Palmarosa. Crop Research. 10(3) : 365-369.

Maheswari, S. K., S. Yadav and R. S. Gupta. (1984). Fertilizer needs of Palmarosa oil grass (Cymbopogon martinii Var. Motia) under rainfed condition of Madhya Pradesh. Indian Perfum. 28(2) : 77-81.

Munsi, P. S. and S. K. Mukherjee. (1982). Effect of fertilizer treatments on yield and economics of cultivation of Mentha, Citronella and Palmarosa. Indian Perfumer. 26A : 9.

Munsi, P. S. and S. K. Mukherjee. (1989). Effect of nitrogen and phosphorus nutrition on yield and quality of Palmarosa oil. In agro systems management proceedings of a National Symposium held at Visva Bharati, Srinikethan, West Bengal on 1989.

Nair, E. V. G., N. P. Chinnamma and P. K. Kumari. $\left(1979^{\mathrm{a}}\right)$. (Lemongrass Res. Stn. Odakkali, Kerala, India). Effect of different levels of nitrogen on three varieties of lemongrass viz., OD-19, SD-68 and RBL-16. Indian Perfum. 23(384) : 202-204.

Pal, S., S. Chandra, S. S. Balyan, A. Singh, B. L. Rao. (1992). Nitrogen requirement of new lemongross strain CKP-25. Indian Perfumer. 36(1): 75-80.

Pareek, S.K., M. L. Maheswari and R. S. Gupta. (1981). Effect of N, P and K fertilizers on yields and quality of Palmarosa grass under cultivation. Indian J. Agron. 96(2): 122-129.

Prakasha Rao, E. V. S., M. R. Narayana, Munnu Singh, Puttanna. (1985). Effect of NPK fertilizers on growth yield and nutrient uptakes in Java citronella (Cymbopogon winterianus Jowitt). Z. Ackerp Flazerb. 15(2) : 279-283.

Rajan, K. C., N. Sadanandan and E. V. G. Nair. (1984). Aromatic and medicinal plants research station Asamannoor. 683-549 Odakkali, Kerala. Agric. Res. J. Kerala. 22(1) : 37-42.

Rao, B. R. R., P. N. Kailash Singh, A. K. Kaul and Bhattacharya. (1990). Response of Palmarosa (Cymbopogon martinii Var. Motia) N plant spacing and nitrogen fertilizer application. Int. J. Trop. Agric. 8(3) : 177-183.

Rao, E. V. S. P., Munnu Singh, E. V. S. Prakasha Rao and M. Singh. (1991). Long term studies on yield and quality of Java citronella (Cymbopogon winterianus Jowitt). Relation to nitrogen application. J. Essential oil Res. 3(6) : 419-429.

Ram, P., Bijendra Kumar, M. Yaseen, S. K. Kothari and D. K. Rajput. (1999). Productivity of Citronella Java based on inter cropping system as effected by fertility levels under Tarai region of U.P. Souvenir Cum Abst. 21(1) : 17.

Randhawa, G. S. and R. K. Mahey. (1985). Research and development of essential oils in Punjab. Indian Perfum. 29(1and2) : 99-104.

Santhi, V. P. and M. Vijay Kumar. (1998). Effect of nitrogen levels and biofertilizers on growth herbage and essential oil yield of Palmarosa. South Indian Horticulture. 45(3/6) : 171-175.

Sarma, J. S., S. S. Saini and D. S. Bains. (1977). Influence of row spacing N and P application of fresh herb and oil yield of Palmarosa (Cymbopogon mantinii Var. Motia). Indian Perfum. 21(1) : 44-46.

Sharma, S. N., A. Singh and R. S. Tripathi. (1980). Response of Palmarosa to nitrogen phosphorus potassium and zinc. Indian J. Agron. 25(4): 719-723. 
Singh, V. P., K. Singh and J. P. Singh. (1983). (Cent Inst Meds Aromat plants, Reg cent, Pantnagar, Nainital, UP, India) Response of citronella Java (Cymbopogon winterianus) to nitrogen phosphorus and potassium fertilization. Indian Perfum. 27(384): 153-155.

Singh, R. P., Singh Bijendra, Singh Vinay, B. Singh and V. Singh. (1994). Effect of RSC in irrigation water on citronella java under different levels of fertilizers. J. Indian Society of Soil Sci. 42(1) : 164-165.

Virmani, O. P., R. Shrivastave and G. N. Shrivastava. (1997). Lemongrass and its cultivation farm Bull No. 6 CIMAP, Lucknow. pp 14.

Vitkare, D. G., S. S. Phasate, K. B. Zade and K. S. Paulkar. (1990). Effect of nitrogen and phosphorus fertilization on the oil content and quality of Lemongrass. PKV Res. J. 14(1): 64-66. 